\title{
TNF-alpha increases angiogenic potential in a co-culture system of dental pulp cells and endothelial cells
}

\author{
Li $A N^{(a)}$ (D) \\ Shuai SHEN(a) \\ Luyao WANG ${ }^{(a)}$ \\ Yong LI(b) (ID) \\ Sidra FAHIM(c) \\ Yumei NIU(a) \\ Shuang PAN(a) \\ (a) Harbin Medical University, The First \\ Affiliated Hospital, Department of \\ Endodontics, Harbin, China. \\ (b) Harbin Medical University, The First \\ Affiliated Hospital, Department of Oral and \\ Maxillofacial Surgery, Harbin, China. \\ (c)Altamash Institute of Dental Medicine, \\ Department of Periodontology/Oral \\ Medicine, Karachi, Pakistan.
}

Declaration of Interests: The authors certify that they have no commercial or associative interest that represents a conflict of interest in connection with the manuscript.

\section{Corresponding Author:}

Pan Shuang

E-mail: panshuang@hrbmu.edu.cn

hitps://doi.org/10.1590/1807-3107bor-2019.vol33.0059

Submitted: November 1, 2018

Accepted for publication: April 14, 2019

Last revision: June 12, 2019

\begin{abstract}
We recently demonstrated that a co-culture system of human umbilical vein endothelial cells (HUVECs) and human dental pulp stem cells (hDPSCs) could enhance angiogenesis ability in vitro. However, whether tumor necrosis factor $\alpha$ (TNF- $\alpha$ ) could promote blood vessel formation during pulp regeneration remained unknown. The aim of this study was to investigate the effects of TNF- $\alpha$ on the formation of endothelial tubules and vascular networks in a co-culture system of hDPSCs and HUVECs. hDPSCs were co-cultured with HUVECs at a ratio of 1:5. The Matrigel assay was performed to detect the total tubule branching lengths and numbers of branches, and the Cell-Counting Kit 8 assay was performed to examine the effect of TNF- $\alpha$ on cell proliferation. Real-time polymerase chain reactions and western blot were used to detect vascular endothelial growth factor (VEGF) mRNA and protein expression. The Matrigel assay showed significantly greater total branching lengths and numbers of branches formed in the experimental groups treated with different concentrations of TNF- $\alpha$ compared with the control group. The decomposition times of the tubule structures were also significantly prolonged $(P<0.05)$. Treatment with $50 \mathrm{ng} / \mathrm{ml} \mathrm{TNF-} \alpha$ did not significantly change the proliferation of co-cultured cells, but it significantly increased the VEGF mRNA and protein expression levels $(\mathrm{p}<0.05)$. In addition, the migration abilities of HUVECs and hDPSCs increased after co-culture with TNF- $\alpha(p<0.05)$. TNF- $\alpha$ enhanced angiogenic ability in vitro in the co-culture system of hDPSCs and HUVECs.
\end{abstract}

Keywords: Neovascularization, Physiologic; Stem Cells.

\section{Introduction}

Angiogenesis is defined as the formation of new capillaries extending from existing blood vessels. ${ }^{1}$ This type of blood vessel development is indispensable for physiological processes such as wound healing and reproduction. It is a complex, dynamic process involving the following steps: degradation of the basement membrane and extracellular matrix surrounding the endothelial cells, endothelial cell proliferation and migration, tube formation, and maturation into functional blood vessels (e.g., recruitment of mural cells).1,2,3,4 The dental pulp is located in the center of the pulp chamber, surrounded by dentin. The nerves and 
vascular and lymphatic vessels enter the dental pulp through the tooth's narrow apical foramen. Any dental inflammatory process may result in the destruction of the neurovascular network, which may lead to autologous ischemia and dental pulp necrosis. Angiogenesis is an important factor in the survival and differentiation of implanted cells in pulp tissue regeneration, ${ }^{5}$ which is not only an important part of pulp tissue engineering, but also plays a key role in enhancing the formation of vascular networks. Several in vitro studies have shown that human dental pulp stem cells (hDPSCs) can promote the formation of tubules in human umbilical vein endothelial cells (HUVECs) in a paracrine manner in co-culture systems. ${ }^{6}$ In vivo studies have shown that hDPSCs regulate angiogenesis by secreting vascular endothelial growth factor (VEGF), a key regulator of vascular permeability and angiogenesis, thereby enhancing the survival and differentiation of HUVECs in paracrine and/or autocrine manners. ${ }^{6,7}$ The present study also shows that a co-culture system of HUVECs and hDPSCs can enhance angiogenesis in vitro.

Tumor necrosis factor $\alpha$ (TNF- $\alpha$ ) is preferentially secreted by macrophages in response to bacterial endotoxins, such as lipopolysaccharide (LPS). ${ }^{8}$ LPS plays a major role in the pathogenesis of degenerative diseases involving the dental pulp and surrounding periodontium. ${ }^{8}$ Several lines of evidence implicate TNF- $\alpha$ in the perpetuation of chemotaxis in inflammatory cells and fibroblasts. ${ }^{910,11}$ More importantly, Graves ${ }^{12}$ provided evidence of the involvement of TNF- $\alpha$ in periodontitis. Our previous experiments showed that $50 \mathrm{ng} / \mathrm{ml} \mathrm{TNF}-\alpha$ stimulation increased hDPSC migration in vitro through integrin $\alpha-6$ subunit upregulation. ${ }^{13}$ The role of TNF- $\alpha$ in angiogenesis, however, is controversial. In two in vivo studies, TNF- $\alpha$ at concentrations of $5 \mathrm{ug} / \mathrm{ml}$ and $5-50 \mathrm{ng} / \mathrm{ml}$ induced angiogenesis in the corneas of rabbits and rats, respectively. ${ }^{14,15}$ In in vitro studies, $0.01 \mathrm{ng} / \mathrm{ml} \mathrm{TNF-} \alpha$ induced the proliferation of cultured capillary bovine brain cells and adrenal cortex-derived capillary endothelial cells, but $1 \mathrm{ng} / \mathrm{ml}$ TNF- $\alpha$ inhibited their proliferation. ${ }^{16,17}$

Previous studies showed that $50 \mathrm{ng} / \mathrm{ml}$ TNF- $\alpha$ had no significant effect on the proliferation of
hDPSCs, but that it significantly enhanced their migration ability. ${ }^{13}$ Therefore, the aims of this study were to explore whether TNF- $\alpha$ promotes angiogenic potential in a co-culture system of hDPSCs and HUVECs, and to identify mechanisms potentially underlying this process.

\section{Methodology}

\section{Islolation and culture of cells}

hDPSCs were isolated as described previously. ${ }^{18}$ Briefly, dental pulp tissues were isolated from healthy impacted third molars from donors aged 18-25 years. The cells were cultured in Dulbecco's modified Eagle medium supplemented with $20 \%$ fetal bovine serum, $100 \mathrm{U} / \mathrm{ml}$ penicillin $\mathrm{G}$, and $100 \mathrm{mg} / \mathrm{ml}$ streptomycin at $37^{\circ} \mathrm{C}$ under $5 \% \mathrm{CO} 2$. HUVECs, EC medium, and poly-L-lysine were from Scien Cell (San Diego, CA, USA). The synergistic effects of hDPSCs and HUVECs were examined in direct cell-to-cell contact cultures. Passages 2-4 of each cell type were used in all experiments.

\section{Tubular network formation on matrigel}

To investigate whether co-culture of hDPSCs and HUVECs under TNF- $\alpha$ promotes the formation of endothelial tubules and a blood vessel network, a tubular formation assay was carried out. Briefly, HUVECs $\left(1.5 \times 10^{4} /\right.$ well $)$ co-cultured with hDPSCs (5:1) were seeded in 96-well plates precoated with Matrigel ( $60 \mu \mathrm{l} /$ well; BD Biosciences). TNF- $\alpha$ $(10,30,50$, and $70 \mathrm{ng} / \mathrm{ml})$ was added to the medium in the experimental groups. Images were obtained under an inverted phase-contrast microscope after 3, 6, 9, and $12 \mathrm{~h}$, and analyzed using Image software (National Institutes of Health, Bethesda, MD, USA). The total branching lengths and the number of branches were measured on the images at $10 \times$ magnification $(n=6)$.

\section{Cell-Counting Kit 8 (CCK-8) assay}

HUVECs and hDPSCs (5:1) were seeded at a density of 2,400 cells/well in 96-well plates. They were treated with $50 \mathrm{ng} / \mathrm{ml}$ TNF- $\alpha$ after $10 \mathrm{~h}$ culture. After culturing for $3,6,9,12,24,48$, and $72 \mathrm{~h}$ at $37^{\circ} \mathrm{C}$, co-cultured cell proliferation was assessed 
by Cell-Counting Kit 8 (CCK-8) assay (Beyotime Institute of Biotechnology). The absorbance of each well was measured at $450 \mathrm{~nm}$. A total of six replicate wells were assayed for each group, and mean values were calculated.

\section{Live/dead staining}

The lattice structures formed by HUVECs and hDPSCs were rinsed twice with Dulbecco's phosphate-buffered saline (PBS; Gibco, Grand Island, NY, USA) to remove serum esterases and then incubated for $30 \mathrm{~min}$ at room temperature in a mixture of $2 \mu \mathrm{M}$ calcein acetoxymethyl (AM; Invitrogen, Waltham, MA, USA) and $4 \mu$ M ethidium homodimer-1 (Invitrogen). Live (calcein AM-labeled, green) and dead (ethidium homodimer-1-labeled, red) cells were visualized under a fluorescence microscope (IX 71; Olympus, Tokyo, Japan).

\section{Immunofluorescent staining}

To distinguish the positional relationships between HUVECs and hDPSCs in vessel-like structures, hDPSCs were stained with DAPI and HUVECs were stained with double immunofluorescent stain for CD31. Briefly, the vessel-like structures formed by hDPSCs and HUVECs were fixed with $4 \%$ paraformaldehyde for $15 \mathrm{~min}$ and blocked in $1 \%$ bovine serum albumin, followed by incubation with rabbit anti-human CD31 (1:20; Abcam) for $1 \mathrm{~h}$ at room temperature. After rinsing with PBS, the cells were treated with secondary antibodies (Alexa 488-conjugated goat anti-rabbit immunoglobulin $\mathrm{G}$, 1:500; Invitrogen) for $1 \mathrm{~h}$ at room temperature. The cells were then stained with DAPI for $30 \mathrm{~min}$. Images were obtained under a fluorescence microscope (IX 71; Olympus). At 200× magnification, migrated cells within five random microscopic fields per well were photographed and counted. The total number of cells was calculated as the average of three independent experiments.

\section{Boyden chamber migration assay}

hDPSCs $\left(3 \times 10^{4}\right)$ were seeded into the upper compartment of the chamber $(8 \mu \mathrm{m}$ pore size; $\mathrm{BD}$ Biosciences). Then, HUVECs $\left(1.5 \times 10^{5}\right)$ with aliquots of $500 \mu \mathrm{l}$ culture medium with or without $50 \mathrm{ng} /$ $\mathrm{ml}$ TNF- $\alpha$ were added to the lower compartment. In the second step, HUVECs $\left(2 \times 10^{4}\right)$ were added to the upper compartment of the chamber while the lower compartment was filled with hDPSCs $\left(4 \times 10^{3}\right)$ with aliquots of $500 \mathrm{ul}$ culture medium with or without $50 \mathrm{ng} / \mathrm{ml}$ TNF- $\alpha$. After culturing for $24 \mathrm{~h}$ at $37^{\circ}$, cells that had migrated through the polycarbonate membrane were fixed with $4 \%$ paraformaldehyde and stained with DAPI. At 100x magnification, migrated cells within five random microscopic fields per well were photographed and counted. The total number of cells was calculated as the average of three independent experiments.

\section{Real-time polymerase chain reaction}

Total cellular RNA was isolated from hDPSCs and HUVECs using the TRIzol reagent (Invitrogen). The isolated RNA was reverse transcribed into cDNA using Superscript III RNase Reverse Transcriptase (Invitrogen), and real-time PCR was performed. Reactions were performed at $95^{\circ} \mathrm{C}$ for 10 minutes followed by 40 cycles of $95^{\circ} \mathrm{C}$ for 30 seconds and $60^{\circ} \mathrm{C}$ for 30 seconds. GAPDH were considered as the housekeeping genes. Each sample was tested in triplicate. The following forward and reverse primers were used: VEGF: 5'-ATCCAATCGAGACCCTGGTG-3' and 5'-ATCTCTCCTATGTGCTGGCC-3'; GAPDH: 5'-TCA AGA AGGTGGTGA AGCAGG-3' and 5'-TCAAAGGTGGAGGAGTGGGT-3'.

\section{Western blot analyses}

HUVECs and hDPSCs (5:1) grown in 75-cm2 flasks were treated with or without $50 \mathrm{ng} / \mathrm{ml} \mathrm{TNF}-\alpha$ for 3 , 6,9 , and $12 \mathrm{~h}$. Total proteins were obtained from the control and experimental groups and lysed in protein lysis buffer (Beyotime, China). The protein content was quantified using the bicinchoninic acid assay (Beyotime, China). Protein extracts were separated via $15 \%$ sodium dodecyl sulfate polyacrylamide gel electrophoresis, and the proteins were electronically transferred to a $0.22-\mathrm{mm}$ polyvinylidene difluoride membrane (Bio-Rad, USA). Western blot analysis was performed as described previously. ${ }^{18}$ 


\section{Statistical analysis}

All experiments were repeated at least three times. Values are presented as means \pm standard deviations. Statistical analyses were conducted with Student's t-test using SPSS software (version 20.0). $P<0.05$ was accepted as statistically significant.

\section{Results}

\section{TNF- $\alpha$ enhanced the formation of vessel-like structures in the co-culture system of HUVECs and hDPSCs}

To determine the optimal concentration of TNF- $\alpha, 0,10,30,50$, and $70 \mathrm{ng} / \mathrm{ml}$ TNF- $\alpha$ were added to the co-culture system of hDPSCs and HUVECs. The co-culture system with TNF- $\alpha$ formed an extensive and stable lattice of vessel-like structures (Figure 1A).The total branching lengths and numbers of branches formed in the experimental groups treated with different concentrations of TNF- $\alpha$ were significantly greater than those in the control group, and the decomposition times of tubule structures were significantly prolonged (both $\mathrm{p}<0.05$ ). The tubule structures formed in the $50-\mathrm{ng} / \mathrm{ml}$ TNF- $\alpha$ group had the greatest total branching lengths and numbers of branches, and remained intact with no obvious decomposition after $24 \mathrm{~h}$. The tubule structures in the control group had the least total branching lengths and numbers of branches. They began to decompose, even collapsing and disappearing, after $6 \mathrm{~h}$. The cells were clustered and the tubule structures was almost completely decomposed at $24 \mathrm{~h}$ (Figures 1B, C). Therefore, $50 \mathrm{ng} / \mathrm{ml} \mathrm{TNF-} \alpha$ was used in subsequent experiments.

\section{Co-cultured hDPSCs and HUVECs showed good growth status under the action of TNF- $\alpha$}

To investigate the effects of exogenous TNF- $\alpha$ on the proliferation of hDPSCs and HUVECs in the co-culture system, we performed the CCK-8 assay. The numbers of hDPSCs and HUVECs in the co-culture system, indicated by the optical density (OD) values, were not increased in the experimental group compared with the control group at 3, 6, 9, 12, 24, 48, or $72 \mathrm{~h}$ (Figure 2A). The lattice structures in the experimental and control groups were immunostained using a live/dead viability/cytotoxicity kit. Following exposure to $50 \mathrm{ng} / \mathrm{ml} \mathrm{TNF}-\alpha$, green fluorescence-stained cells formed stable and uniform tubule-like structures and no red fluorescent cells were observed, indicating good growth status of the co-cultured hDPSCs and HUVECs (Figure 2B). The lattice structures were composed of 2-5 layers of cells, with extensive crosslinking and denser network structures in the experimental group compared with the control group. The lattice structures in both groups were immunostained with CD31, a specific marker of vascular endothelial cells. CD31+ vascular endothelial cells were located in the areas surrounding the main tubules in both groups (Figure 2C).

\section{VEGF was upregulated in the co-culture system of hDPSCs and HUVECs under TNF- $\alpha$}

The expression level of VEGF under the action of TNF- $\alpha$ was explored at the genetic level. To study changes in VEGF, differential expression was analyzed by quantitative PCR after 3, 6, 9 and $12 \mathrm{~h}$ treatment with $50 \mathrm{ng} / \mathrm{ml}$ TNF- $\alpha$. VEGF gene expression was significantly up-regulated at all time points ( $p<0.05$; Figure 3A). The expression level of VEGF in the co-culture system under the action of TNF- $\alpha$ was examined at the protein level by western blot assay. VEGF protein expression increased significantly upon treatment with $50 \mathrm{ng} / \mathrm{ml}$ TNF- $\alpha$ for 3, 6, 9, and $12 \mathrm{~h}$. However, no significant difference in this expression among the experimental groups was observed at any time point $(\mathrm{p}<0.05$; Figures 3B, C).

\section{The TNF-a level was correlated directly with increased hDPSC and HUVEC migration}

To assess the regulatory effects of TNF- $\alpha$ on the migration of hDPSCs and HUVECs in the co-culture systems, we used polycarbonate migration filters coated and uncoated with TNF- $\alpha$ (50 ng/ml). Numbers of migrated cells were determined at different time points using transwell migration 
A
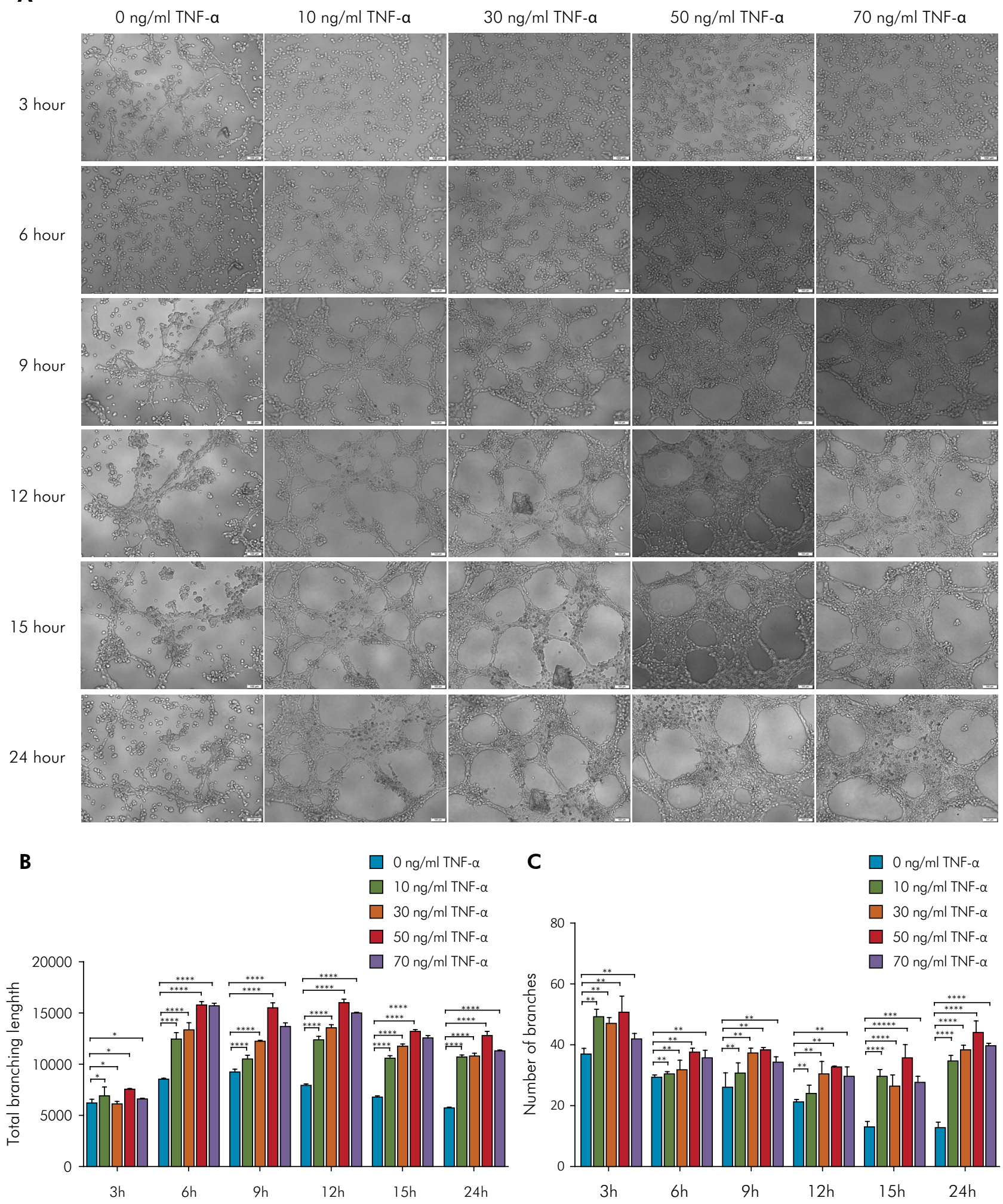

Figure 1. Dose-dependent modulation of vessel formation by TNF- $\alpha$. (A) Phase-contrast images $(\times 10)$ at $3,6,9,12,15$, and $24 \mathrm{~h}$ after the addition of $0,10,30,50$, and $70 \mathrm{ng} / \mathrm{ml}$ TNF- $\alpha$ to the co-culture system (HUVECs:hDPSCs $=5: 1$ ), with seeding on Matrigel. $(B, C)$ Graphic representations of the total branching length and number of branches, respectively. Data are presented as means \pm standard deviations $(n=5)$. 

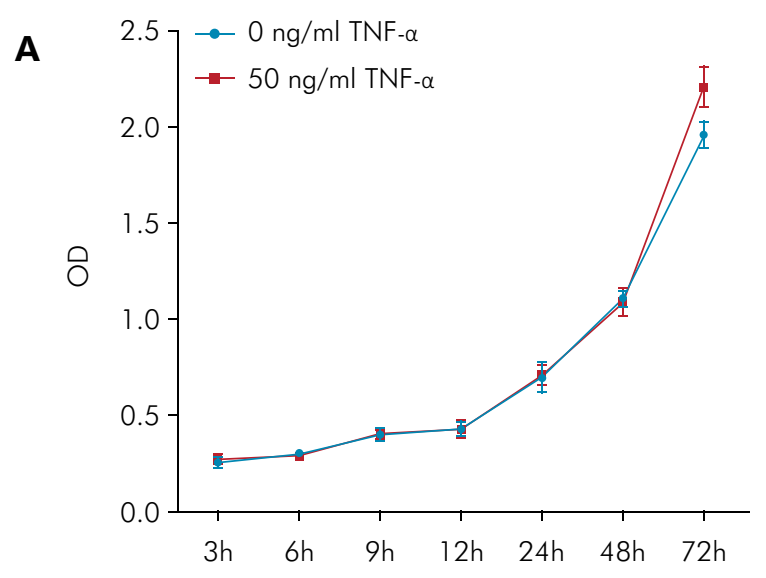

B

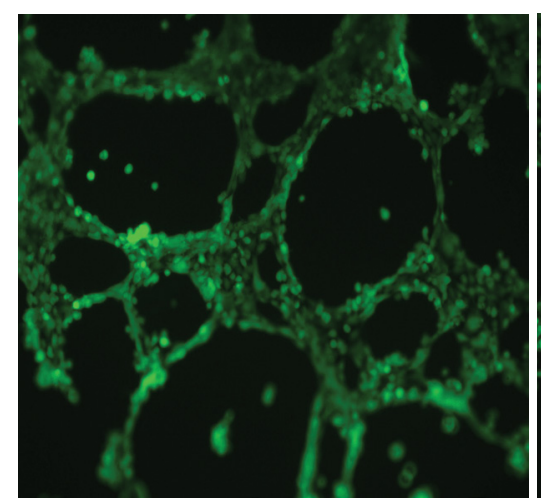

$0 \mathrm{ng} / \mathrm{ml} \mathrm{TNF- \alpha}$

C

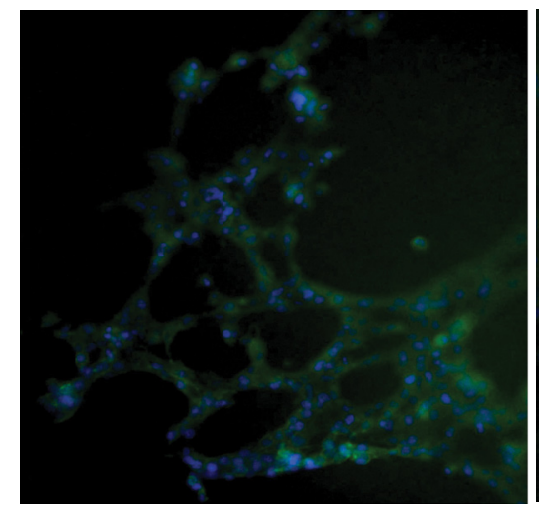

$0 \mathrm{ng} / \mathrm{ml} \mathrm{TNF- \alpha}$

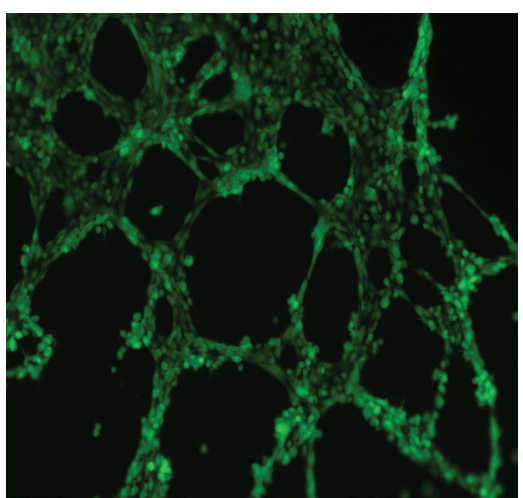

$50 \mathrm{ng} / \mathrm{ml}$ TNF- $\alpha$

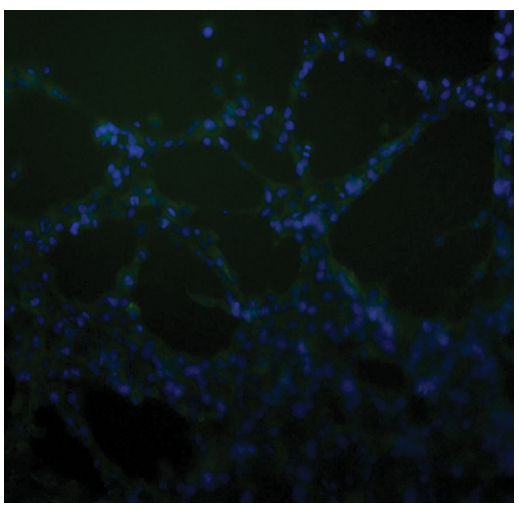

$50 \mathrm{ng} / \mathrm{ml} \mathrm{TNF- \alpha}$

Figure 2. TNF- $\alpha$ had limited effects on the proliferation abilities of hDPSCs and HUVECs in the co-culture system. (A) The proliferation of hDPSCs and HUVECs was analyzed using Cell Counting Kit 8 at 3, 6, 9, 12, 24, 48, and 72 h under the action of $50 \mathrm{ng} / \mathrm{ml} \mathrm{TNF-} \alpha$. OD values of the two groups of cells were comparable during the 8 -day observation period. Data are presented as means \pm standard deviations (error bars). (B) Live (green)/dead (red) staining of the lattice structures formed by the co-cultured system in the presence and absence of $50 \mathrm{ng} / \mathrm{ml} \mathrm{TNF- \alpha .} \mathrm{(C)} \mathrm{CD31} \mathrm{(immunofluorescence)-stained} \mathrm{vessel-like} \mathrm{structures} \mathrm{formed} \mathrm{by}$ HUVECs in co-culture. Green fluorescence indicates CD31 positivity, and blue staining indicates nuclei.

assays (Figure 4B). DAPI staining of hDPSCs and HUVECs subjected to transwell assays revealed that the migration ability of these cells correlated positively with the TNF- $\alpha$ level, as compared with the control group ( $\mathrm{p}<0.05$; Figure $4 \mathrm{~A})$.

\section{Discussion}

Regenerative endodontic treatment is a branch of regenerative medicine and tissue engineering that can be defined as a biologically based restorative 
A

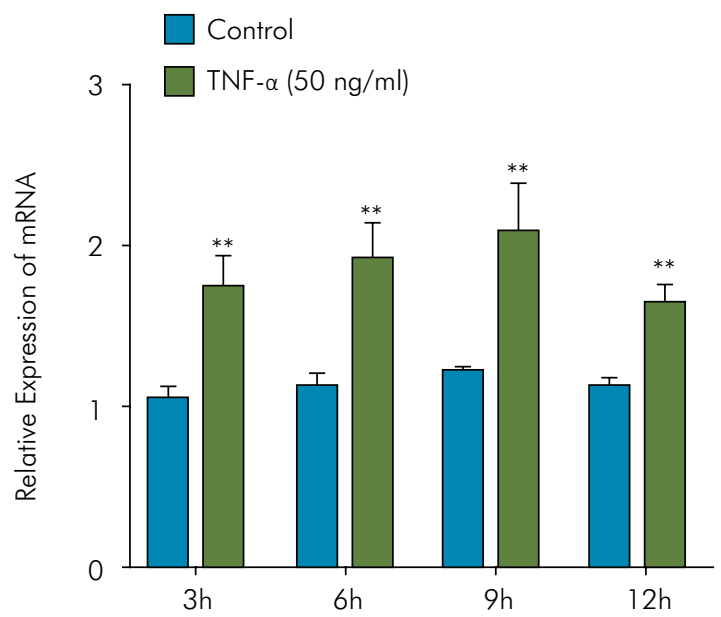

B
$3 \mathrm{~h}$
$6 \mathrm{~h}$
$9 h$
$12 \mathrm{~h}$

VEGF

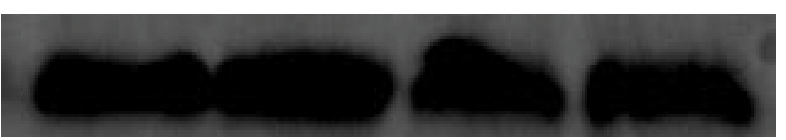

$50 \mathrm{ng} / \mathrm{ml} \mathrm{TNF- \alpha}$

GAPDH

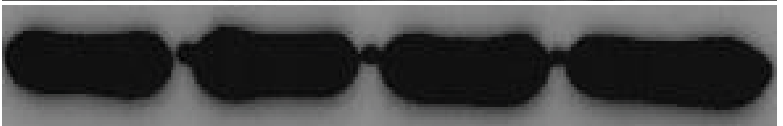

$50 \mathrm{ng} / \mathrm{ml} \mathrm{TNF- \alpha}$

VEGF

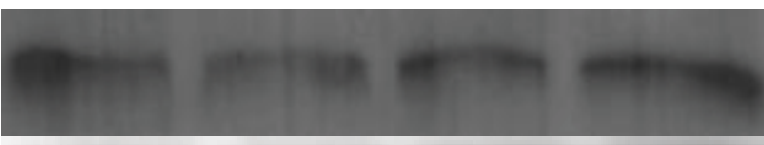

$0 \mathrm{ng} / \mathrm{ml}$ TNF- $\alpha$

GAPDH

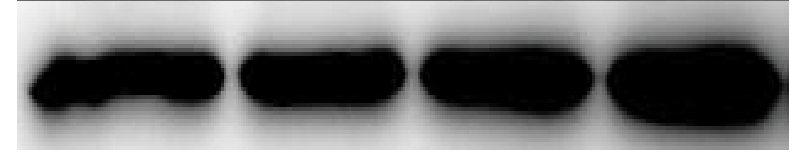

$0 \mathrm{ng} / \mathrm{ml} \mathrm{TNF}-\alpha$

\section{C}

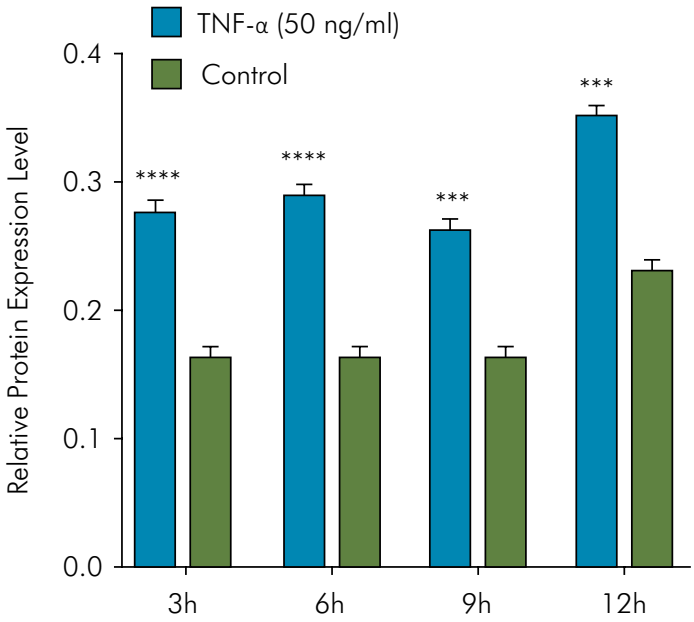

Figure 3. TNF- $\alpha$ promoted the expression of VEGF mRNA and protein. (A) Relative expression levels of VEGF under the action of $50 \mathrm{ng} / \mathrm{ml}$ TNF- $\alpha$ at different time points, detected by real-time PCR. Values are normalized to GAPDH expression $(* * P<0.01)$. (B) Western blotting showing positivity for VEGF protein expression in the co-culture system with $50 \mathrm{ng} / \mathrm{ml}$ TNF- $\alpha$. VEGF expression was upregulated under the action of TNF- $\alpha$ at 3, 6, 9, and $12 \mathrm{~h}$. Electrophoresis was performed on $15 \%$ polyacrylamide gel, and the density of each band was measured and normalized to that of GAPDH. (C) Relative protein expression levels of VEGF were increased in the experimental groups compared with the control groups. Experiments were repeated at least three times. Values are expressed as means \pm standard deviations. $\left({ }^{* * *} p<0.001,{ }^{* * * *} p<0.0001\right)$. 


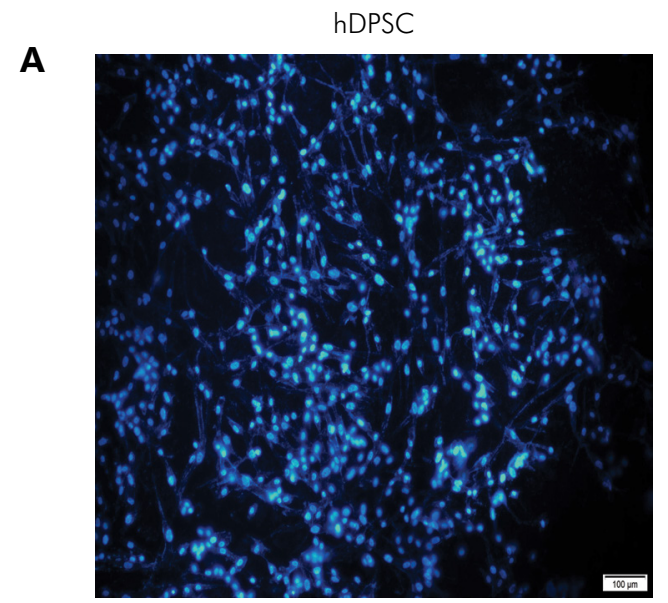

HUVEC

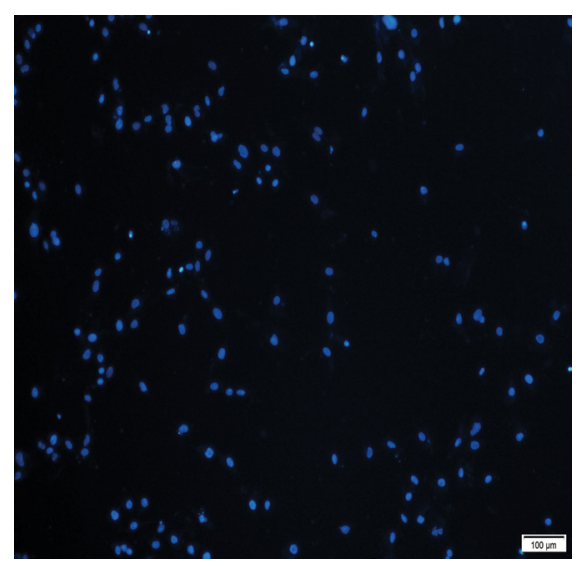

B

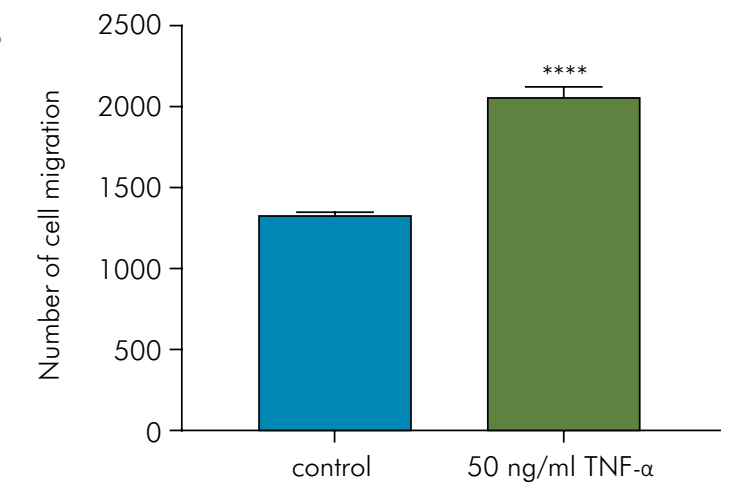

$\mathrm{hDPSC}+50 \mathrm{ng} / \mathrm{ml} \mathrm{TNF}-\alpha$

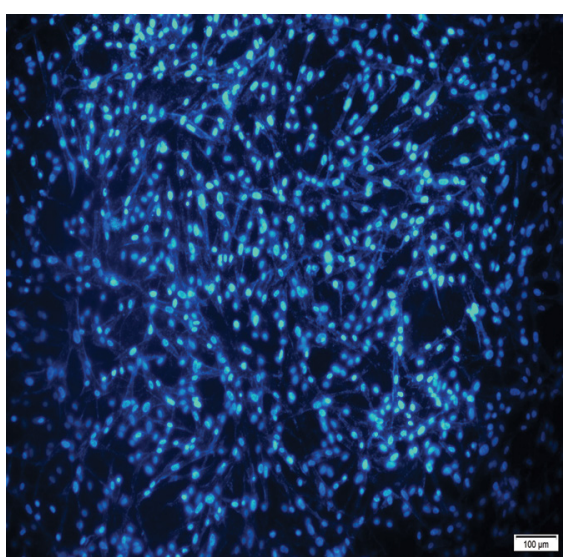

HUVEC $+50 \mathrm{ng} / \mathrm{ml}$ TNF- $\alpha$
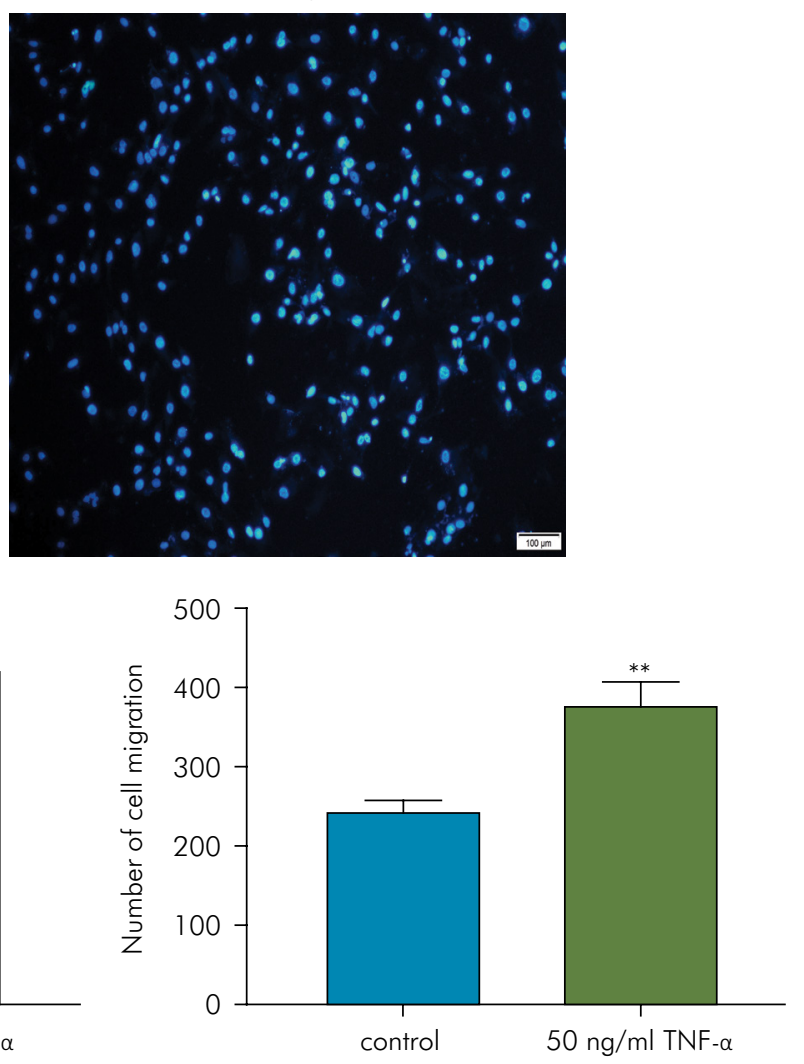

Figure 4. TNF- $\alpha$ enhanced the migration abilities of hDPSCs and HUVECs. (A) The numbers of migrated cells with $50 \mathrm{ng} / \mathrm{ml}$ TNF- $\alpha$ and control incubation for $24 \mathrm{~h}$ were compared using the transwell assay. Photographs show DAPI-stained cells from two wells from three different experiments that migrated to the lower surface; five random fields per well were counted. (B) Mean numbers of hDPSCs and HUVECs that migrated in response to TNF- $\alpha(50 \mathrm{ng} / \mathrm{ml})$, determined by cell counting at $100 \times$ magnification $\left(* * p<0.01 i^{* * * *} p<0.0001\right.$ vs. control).

approach to the replacement of lost or damaged pulp tissue with hDPSCs, suitable biochemical factors, and engineering materials. ${ }^{19,20}$ If blood vessel formation toward the transplanted tissue cannot be established rapidly, necrosis of the transplant will occur. ${ }^{21} \mathrm{hDPSC}$ are present in dental pulp, and their function is to regenerate damaged pulp, based on their potential to form dentin-tooth pulpoid tissues in 
vivo. ${ }^{22}$ Angiogenesis is key for the regeneration of the pulp-dentin complex. ${ }^{6,23}$ In preliminary experiments, we showed that HUVECs and hDPSCs co-cultured at a ratio of 5:1 formed more tubule structures in the early stage, but began to collapse at about $6 \mathrm{~h}$. As the tubule structures were not sufficiently stable, we added TNF- $\alpha$ to the co-culture system to improve stability.

In Matrigel tube formation experiments, the total branching lengths and numbers of branches of the tubule-like structures were much greater with the addition of $50 \mathrm{ng} / \mathrm{ml} \mathrm{TNF-} \alpha$ than in the control group and groups treated with other TNF- $\alpha$ concentrations. In addition, $50 \mathrm{ng} / \mathrm{ml}$ TNF- $\alpha$ promoted the formation of broader, stable lattice structures and prolonged their decomposition times. Therefore, $50 \mathrm{ng} / \mathrm{ml} \mathrm{TNF}-\alpha$ was determined to be the optimal concentration and was used in all subsequent experiments. Live/dead staining of the lattice structures showed that HUVECs and hDPSCs grew well, with no dead cells observed.

Quiescent stem cell populations form regenerative hubs in dental tissues; they reside in a latent state and are evoked to proliferation, migration, and differentiation only after stimulation by cytokines released after injury. ${ }^{24,25}$ TNF- $\alpha$ is a cytokine released early in the pulp during inflammation, ${ }^{26}$ but whether it promotes the formation of lattice structures by stem cells had not been studied before the present work. The CCK- 8 assay showed that TNF- $\alpha$ had limited effects on the proliferation abilities of hDPSCs and HUVECs in the co-culture system. Thus, the ability of TNF- $\alpha$ to enhance lattice structure formation is not achieved by promoting the proliferation of these cells.

Another key step in angiogenesis is EC migration; thus, we investigated whether TNF- $\alpha$ promoted the formation of lattice structures by promoting the migration of HUVECs and hDPSCs. The migration abilities of these cells correlated positively with the TNF- $\alpha$ level. This result is consistent with our group's previous experimental finding that $50 \mathrm{ng} /$ $\mathrm{ml}$ TNF- $\alpha$ promotes the migration ability of hDPSCs in vitro. Thus, the results of the present study show that $50 \mathrm{ng} / \mathrm{ml}$ TNF- $\alpha$ promoted the formation of lattice structures by promoting the migration ability of hDPSCs and HUVECs in the co-culture system.

Enhanced cellular differentiation and neovascularization of dental pulp tissue are important steps in the healing of dental pulp. ${ }^{27}$ The potential for pulp healing is related to the ability of dental pulp cells to secrete growth factors, including angiogenic factors, platelet-derived growth factor, and fibroblast growth factor. ${ }^{28}$ These cytokines have been shown to play major roles as secondary mediators of TNF- $\alpha$-induced angiogenesis through paracrine and/or autocrine actions. ${ }^{29-33}$ Moreover, TNF- $\alpha$ and LPS can activate angiogenesis via VEGF and SIRT1 signaling in human dental pulp cells. ${ }^{34}$ One in vitro study revealed that VEGF promoted proliferation and differentiation of hDPSCs. ${ }^{35}$ As an endothelial cell mitogen ${ }^{36}$ and growth factor ${ }^{37}$ VEGF can recruit new blood vessels to the region closest to bacterial invasion. In the present study, western blot analysis and real-time PCR showed that the expression level of the angiogenic marker VEGF was significantly increased under the action of $50 \mathrm{ng} / \mathrm{ml}$ TNF- $\alpha$ compared with the control group. Therefore, consistent with previous findings, $50 \mathrm{ng} / \mathrm{ml} \mathrm{TNF}-\alpha$ enhanced the formation of lattice structures in vitro in the co-culture system through the upregulation of VEGF expression.

In cellular transplants, stem cells have been shown to promote angiogenesis in two distinct fashions: a. through the secretion of angiogenic factors to induce the formation of blood vessels from the host tissue and $b$. through differentiation into endothelial cells as constituents of the newly formed vascular structures. ${ }^{38}$ Pericytes, also called perivascular cells, are located in the basement membranes of vessels and interact with endothelial cells to regulate blood vessel physiology. ${ }^{39,40}$ Dental pulp stem cells may originate from pericytes. The dentin matrix is degraded when the pulp is damaged, and pericytes migrate from the capillary wall to the area around the pulp tissue. In this study, all cells constituting the tubule structures were CD31 positive, suggesting that $\mathrm{hDPSC}$ s played a functional role in angiogenesis by differentiating into vascular endothelial cells in the co-culture system in vitro.

In sum, hDPSCs and HUVECs formed a large number of stable lattice structures in the co-culture system, accompanied by the upregulation of VEGF mRNA and protein expression levels and increased migration ability of HUVECs and hDPSCs under the action of $50 \mathrm{ng} / \mathrm{ml}$ TNF- $\alpha$. Thus, the co-culturing 
of HUVECs and hDPSCs with TNF- $\alpha$ can increase angiogenic potential in vitro. However, the specific signaling pathways and mechanisms by which $50 \mathrm{ng} / \mathrm{ml}$ TNF- $\alpha$ induced revascularization in the co-culture system in vitro, as well as the best method of TNF- $\alpha$ application in vivo to promote pulp revascularization, require further study.

\section{Acknowledgements}

This study was supported by grants from the Nature Science Foundation of China (Project No.81570963). The authors appreciate Mr.Qiusheng Shan, Department of Oral and Maxillofacial Surgery, the First Affiliated Hospital of Harbin Medical University, for his generous suggestions and proofreading for the manuscript.

\section{References}

1. Mauger MJ, Schindler WG, Walker WA. An evaluation of canal morphology at different levels of root resection in mandibular incisors. J Endod. 1998 Sep;24(9):607-9. https://doi.org/10.1016/S0099-2399(98)80120-9

2. Wu MK, R'Oris A, Barkis D, Wesselink PR. Prevalence and extent of long oval canals in the apical third. Oral Surg Oral Med Oral Pathol Oral Radiol Oral Endod. 2000 Jun;89(6): 739-43. https://doi.org/10.1067/moe.2000.106344

3. Versiani MA, Pécora JD, Sousa-Neto MD. Flat-oval root canal preparation with self-adjusting file instrument: a micro-computed tomography study. J Endod. 2011 Jul;37(7):1002-7. https://doi.org/10.1016/i.joen.2011.03.017

4. Almeida MM, Bernardineli N, Ordinola-Zapata R, Villas-Bôas MH, Amoroso-Silva PA, Brandão CG, et al. Micro-computed tomography analysis of the root canal anatomy and prevalence of oval canals in mandibular incisors. J Endod. 2013 Dec;39(12):1529-33. https://doi.org/10.1016/j.joen.2013.08.033

5. Azim AA, Piasecki L, Neto UXS, Cruz ATG, Azim KA. Xp shaper, a novel adaptive core rotary instrument: micro-computed tomographic analysis of its shaping abilities. J Endod. 2017; 43(9):1532-8. https://doi.org/10.1016/i.joen.2017.04.022

6. Wu MK, Sluis LW, Wesselink PR. The capability of two hand instrumentation techniques to remove the inner layer of dentine in oval canals. Int Endod J. 2003 Mar; 36(3): 218 -24. https://doi.org/10.1046/i.1365-2591.2003.00646.x

7. Weiger R, ElAyouti A, Löst C. Efficiency of hand and rotary instruments in shaping oval root canals. J Endod. 2002 Aug;28(8):580-3. https://doi.org/10.1097/00004770-200208000-00004

8. Zmener O, Pameijer $\mathrm{CH}$, Banegas $\mathrm{G}$. Effectiveness in cleaning oval-shaped root canals using anatomic endodontic technology, profile and manual instrumentation: a scanning electron microscopic study. Int Endod J. 2005 Jun; 38(6):356-63. https://doi.org/ 10.1111/j.1365-2591.2005.00938.x

9. Zmener O, Pameijer CH, Banegas G. Retreatment efficacy of hand versus automated instrumentation in oval-shaped root canals: an ex vivo study. Int Endod J. 2006 Jul;39(7):521-6. https://doi.org/ 10.1111/i.1365-2591.2006.01100.x

10. Rüttermann S, Virtej A, Janda R, Raab WH. Preparation of the coronal and middle third of oval root canals with a rotary or an oscillating system. Oral Surg Oral Med Oral Pathol Oral Radiol Endod. 2007 Jun; 104(6):852-6. https://doi.org/10.1016/j.tripleo.2007.04.030

11. Coniglio I, Carvalho CA, Magni E, Cantoro A, Ferrari M. Post space debridement in oval-shaped canals: The use of a new ultrasonic tip with oval section. J of Endod 2008 Jun;34(6):752-5. https://doi.org/10.1016/i.joen.2008.03.017

12. De-Deus G, Murad C, Paciornik S, Reis CM, Coutinho-Filho T. The effect of the canal-filled area on the bacterial leakage of oval-shaped canals. Int Endod J. 2008 Mar; 41(3):183-90. https://doi.org/10.1111/j.1365-2591.2007.01320.x

13. Zuolo ML, Zaia AA, Belladonna FG, Silva EJLN, Souza EM, Versiani MA, et al. Micro-ct assessment of the shaping ability of four root canal instrumentation systems in oval-shaped canals. Int Endod J. 2018 May; 51(5):564-71. https://doi.org/10.1111/iej.12810

14. De-Deus G, Belladonna FG, Silva EJNL, Marins JR, Souza EM, Perez R, et al. Micro-ct evaluation of non-instrumented canal areas with different enlargements performed by niti systems. Braz Dent J. 2015 Jun; 26(6):624-9. http://dx.doi.org/10.1590/0103-6440201300116

15. Versiani MA, Ordinola-Zapata R, Keleş A, Alcin H, Bramante CM, Pécora JD, et al. Middle canals in mandibular first molars: a micro ct study in different populations. Arch Oral Biol. 2016 Jan; 61:130-7. https://doi.org/10.1016/i.archoralbio.2015.10.020

16. Peters OA, Bahia MGA, Pereira ESJ. Contemporary root canal preparation. Dent Clin North Am. 2017 Jan;61(1):37-58. https://doi.org/10.1016/j.cden.2016.08.002.

17. Lumley PJ, Walmsley AD, Walton RE, Rippin JW. Cleaning of oval canals using ultrasonic or sonic instrumentation. J Endod. 1993 Sep; 19(9):453-7. https://doi.org/10.1016/S0099-2399(06)80532-7

18. Weller N, Brady JM, Bernier WE. Efficacy of ultrasonic cleaning. J Endod. 1980 Sep; 6(9):740-43. https://doi.org/10.1016/S0099-2399(80)80185-3 
19. Coelho BS, Amaral ROJFD, Leonardi DP, Marques-da-Silva B, Silva-Sousa YTC, Carvalho FMAD, et al. Performance of three single instrument systems in the preparation of long oval canals. Braz Dent J. 2016 Feb;27(2):217-22. http://dx.doi.org/10.1590/0103-6440201302449

20. Ahmed HMA, Versiani MA, De Deus G, Dummer PMH. A new system for classifying root and root canal morphology. Int Endod J 2017 Aug;50(8):761-70. https://doi.org/10.1111/iej.12685

21. ElAyouti A, Chu AL, Kimionis I, Klein C, Weiger R, Löst C. Efficacy of rotary instruments with greater taper in preparing oval root canals. Int Endod J. 2008 Dec;41(12):1088-92. https://doi.org/10.1111/j.1365-2591.2008.01475.x

22. van der Sluis LWM, Vogels MPJM, Vergaagen B, Macedo R, Wesselink PR. Study on the influence of refreshment/activation cycles and irrigants on mechanical cleaning efficiency during ultrasonic activation of the irrigant. J Endod. 2010 Apr; 36(4):737-40. https://doi.org/10.1016/i.joen.2009.12.004

23. Amoroso-Silva P, Alcalde MP, Húngaro-Duarte MA, De-Deus G, Ordinola-Zapata R, Freire LG, et al. Effect of finishing instrumentation using niti hand files on volume, surface area and uninstrumented surfaces in c-shaped root canal systems. Int Endod J. 2017 Jun;50(6):604-11. https://doi.org/10.1111/iej.12660

24. Gergi R, Osta N, Bourbouze G, Zgheib C, Arbab-Chirani R, Naaman A. Effects of three nickel titanium instruments systems on root canal geometry assessed by micro-computed tomography. Int EndodJ. 2015 Feb;48(2):162-70. https://doi.org/10.1111/iej.12296

25. Gambill J, Alder MA, del Rio CE. Comparison of nickel-titanium and stainless steel hand-file instrumentation using computed tomography. J Endod. 1996 Jul;22(7):369-75. https://doi.org/10.1016/S0099-2399(96)80221-4

26. Rhodes JS, Ford TR, Lynch JA, Liepins PJ, Curtis RV. Micro-computed tomography: a new tool for experimental endodontology. Int Endod J. 1999 Mar; 32(3):165-70. https://doi.org/10.1046/i.13652591.1999.00204.x

27. Peters $O A$, Laib A, Rüegsegger P, Barbakow F. Three-dimensional analysis of root canal geometry by high-resolution computed tomography. J Dent Res. 2000 Jun;79(6):1405-9. https://doi.org/10.1177/00220345000790060901

28. Carr GB, Murgel CAF. The use of the operating microscope in endodontics. Dent Clin North Am. 2010;54(2):191-214. https://doi.org/10.1016/i.cden.2010.01.002

29. Perrin P, Neuhaus KW, Lussi A. The impact of loupes and microscopes on vision in endodontics. Int Endod J. 2014 May; 47(5):425-9. https://doi.org/10.1111/iej.12165

30. Michaelides PL. Use of the operating microscope in dentistry. J Calif Dent Assoc. 1996 Jun;24(6):45-50.

31. Wu D, Shi W, Wu J, Wu Y, Liu W, Zhu Q. The clinical treatment of complicated root canal therapy with the aid of a dental operating microscope. Int Dent J. 2011 May;61(5):261-6. https://doi.org/10.1111/j.1875-595X.2011.00070.x

32. Mittal S, Kumar T, Sharma J, Mittal S. An innovative approach in microscopic endodontics. J Conserv Dent. 2014 Mar; 17(3):297-8. https://doi.org/10.4103/0972-0707.131812

33. Goldman M, White R, Moser CR, Tenca JI. A comparison of three methods of cleaning and shaping the root canal in vitro. J Endod. 1988 Jan;14(1):7-12. https://doi.org/10.1016/S0099-2399(88)80235-8

34. Busquim S, Cunha RS, Freire L, Gavini G, Machado ME, Santos M. A micro-computed tomography evaluation of long-oval canal preparation using reciprocating or rotary systems. Int Endod J. 2015 Oct;48(10):1001-6. https://doi.org/10.1111/iej.12398

35. Langeland K, Liao K, Pascon EA. Work-saving devices in endodontics: efficacy of sonic and ultrasonic techniques. J Endod. 1985 Nov;11(11):499-510. https://doi.org/10.1016/S0099-2399(85)80223-5

36. Singh R, Barua P, Kumar M, Safaya R, Monajemi H, Monajemi H. Effect of ultrasonic instrumentation in treatment of primary molars. J Contemp Dent Pract. 2017 Sep;18(9):750-53. https://doi.org/10.5005/ip-journals-10024-2120

37. Pinheiro SR, Alcalde MP, Vivacqua-Gomes N, Bramante CM, Vivan RR, Duarte MAH, et al. Evaluation of apical transportation and centering ability of five thermally treated niti rotary systems. Int Endod J. 2018 Jun; 51(6):705-713. https://doi.org/10.1111/iej.12881

38. Moriya K. Fundamental study of root canal preparation by ultrasonic system. Jpn J Conserv Dent. 1984;27:333-60.

39. Yamaguchi M, Matsumori M, Ishikawa $H$, Sakurai T, Nakamura $H$, Naitoh M, et al. The use of ultrasonic instrumentation in the cleansing and enlargement of the root canal. Oral Surg Oral Med Oral Pathol. 1988 Mar; 65(3):349-53.

https://doi.org/10.1016/0030-4220(88)90121-1 